\title{
The Effect of Overtime Work On Family Social Aspects
}

\author{
M Yusuf ${ }^{1}$ \\ Mechanical Engineering Department \\ Politeknik Negeri Bali \\ Bali, Indonesia \\ 1'yusuf@pnb.ac.id
}

\author{
Wira Ditta Lokantara ${ }^{2}$ \\ Economics Department \\ Universitas Gadjah Mada \\ Yogyakarta, Indonesia \\ ²wiraditta@gmail.com
}

\author{
I Made Anom Santiana ${ }^{3}$, I Wayan Sudiasa ${ }^{4}$ \\ Civil Engineering Department \\ Politeknik Negeri Bali \\ Bali, Indonesia \\ ${ }^{3}$ madeanomsantiana@pnb.ac.id, ${ }^{4}$ wayansudiasa @ pnb.ac.id
}

\begin{abstract}
Overtime is defined as work carried out by employees, on the basis of orders from superiors, which exceeds normal working hours on weekdays, or work carried out on employees' weekly rest days or official holidays. The time and overtime pay are already regulated in Law Number 13 year 2003 concerning Employment, and Decree of the Minister of Manpower and Transmigration of the Republic of Indonesia Number 102/Men/VI/2004. A worker who often overtime will get additional income along with the amount of overtime. So that if it is associated with the theory of family welfare that the amount of income will provide the potential to improve family welfare, or it could be said that the income will affect the welfare of the workers. To see firsthand how the effect of overtime work on family welfare was observed at $\mathrm{CV}$ " $\mathrm{X}$ " in Bali. $\mathrm{CV}$ " $\mathrm{X}$ " is engaged in the industry of sandals, shoes and bags. Observations were made to prove the effect of overtime work on family welfare in terms of income and social aspects. This research was conducted with observational methods, interviews with workers who were married and often received overtime, and literature studies. Literature study is associated with the results of previous studies. The respondents were 27 people who were all married. From the results concluded (a) Overtime work has a significant and positive influence on family welfare in terms of income aspects of workers at $\mathrm{CV}$ " $\mathrm{X}$ " in Bali, (b) overtime work has a significant influence but an inverse effect (negative) on family welfare in terms of social aspects at $\mathrm{CV}$ " $\mathrm{X}$ " in Bali.
\end{abstract}

Keywords-overtime work; social aspect; income aspect; family welfare.

\section{INTRODUCTION}

Overtime is common in every company. Overtime is defined as work carried out by employees, on the basis of orders from superiors, which exceeds normal working hours on weekdays, or work carried out on employees' weekly rest days or official holidays [1]. The time and overtime pay are already regulated in Law Number 13 year 2003 concerning Employment and Decree of the Minister of Manpower and Transmigration of the Republic of Indonesia Number 102/Men/VI/2004 [1]. A worker who often overtime will get additional income along with the amount of overtime. In overtime work case, the additional amount of income will potentially improve family welfare, or hypothetically, income will affect the welfare of the workers.

However also, when we evaluate the workers social aspect, a worker who often works overtime will lose time to gather with family. There is likelihood that socially a worker would be negatively affected from the extra time working on the workplace. We aim to know more deeply the influence of overtime work on family welfare.

A worker's welfare is a fulfillment of physical or spiritual needs, both inside and outside the employment relationship, which all of them can directly or indirectly enhance work productivity together in a safe and healthy work environment. The purpose of welfare is to create motivation. Welfare is positively related to job satisfaction, better working conditions, canteen facilities, bathroom facilities and financial incentives [2].

The welfare of workers will also affect the welfare of their families at home. The level of family welfare is influenced by internal and external factors. Internal factors that affect the level of welfare according to the BKKBN indicator are the age of the family/partner, family level of education, and income; while the external factor is type of residence [3]. These internal and external factors have a significant relationship with family income levels. Husband or wife's income is an important factor in improving family welfare. Families with higher income have a greater chance of prosperity than families with low income, that income will determine the purchasing power of food and other facilities such as education, health, housing, and others. In addition, families who have assets are more prosperous than families without assets [3].

Family income can come from the husband's income alone as the head of the family or supplemented by the wife's income. It can also only be the wife's income if the single 
parent (widow). If the husband / wife is a workforce, the amount of income is the amount of income which includes basic salary, allowances, and overtime pay. The more overtime, the more labor income will increase.

To see firsthand how the influence of overtime work from the social aspect was observed on $\mathrm{CV}$ " $\mathrm{X}$ " in Bali. CV " $\mathrm{X}$ " is engaged in the industry of sandals, shoes and bags. This observation was carried out to prove the effect of overtime work on family welfare in terms of income and social aspects.

\section{RESEARCH METHODOLOGY}

This research includes ex-post facto research. The study design was conducted observationally. The number of respondents is 27 people who work at $\mathrm{CV}$ " $\mathrm{X}$ " which is spread in three regencies in Bali. Observations are made by making questionnaires and conducting interviews with respondents and company owners. Selected respondents are workers who are married and often get overtime work. Data presentation and analysis results are described quantitatively and qualitatively.

\section{RESULTS AND DISCUSSIONS}

\section{A. Overtime and Family Welfare}

In measuring well-being, we can use income received by workers. With the increase in wages (real wages and nominal wages) or income, the welfare of workers will increase, this is due to rising income, workers will be better able to meet their needs.

In economic theory, measured income is divided into permanent or permanent income (permanent income) and nonpermanent income (transitory income, unplanned income, or unanticipated income). In the context of workers, workers' wages are a component of permanent income. Wages are always related to the term's real wages and nominal wages. Wages received by workers are called nominal wages. Real wage is a wage that has been calculated with the purchasing power of received wages or nominal wages.

Family welfare if measured by income earned by the family, both husband and wife income can be seen from the high or low amount of income. Family welfare in terms of social can be measured by meeting the needs of the family both primary and secondary. Meeting the goods needs of a family depends on the purchasing power of the family.

In market theory, the price of goods and services will affect the purchasing power of these workers' wages. It is possible that workers 'nominal wages will increase compared to the previous year, but because the cost of living rises, the purchasing power of workers' wages can be lower than the previous year. Despite the increase, the rate of increase in real wages is nothing compared to the previous year's real wages. Labor wages influence the existence of a minimum life of workers. So the greater the wages received by workers, the greater the level of prosperity, on the contrary if the wages of workers become smaller, the level of prosperity of workers will also be lower [2].
Wage levels will be related to worker productivity. Entrepreneurs are of the view that for workers to earn enough wages to pay for their lives, workers must be able to achieve high levels of productivity, so that wages can be increased. On the contrary, workers view high wages as a means to improve the welfare of workers and their families [4]. This confirms that there is a relationship between the income of workers and the welfare of their families. The higher the wages earned (both wages from basic salary and overtime), the higher the welfare of themselves and their families. The minimum wage must pay attention to the minimum requirements of the welfare of workers and families [5].

From some of the research results above, it can be stated that there is a positive relationship between overtime and wages. The more overtime, the more wages you get. On the other hand, the more wages can be earned then according to the perception of the workers, the higher the family welfare is obtained. However, it needs to be studied as well, is welfare only measured by income level? What about the social conditions of the family if the husband / wife often overtime at work. The welfare of workers is not only measured by the wages earned, but also social factors, such as health insurance for themselves and their families, adequate work facilities, and so on. This shows that family welfare for workers is not only measured by wages (salary, overtime pay, and incentives) but also there are family social welfare factors. The International Labor Organization (ILO) at the Asian Regional Conference defines workers' welfare as a term that includes all services, facilities and facilities in the work environment to enable employees to do their work in a healthy and pleasant environment that is conducive to good health and work morale. high. Workers' welfare includes anything that is done to alleviate working conditions, create industrial harmony, improve health, provide education facilities for employees and families in addition to wages and salaries [6].

From the results of previous studies and the above explanation it can be stated that there is a potential positive relationship between overtime and family welfare. This means that the more overtime is the higher the potential for family welfare. Family welfare here is viewed from the aspect of family income, so it is also necessary to pay attention to family welfare in terms of social aspects.

\section{B. Effect of Overtime Work on Family Welfare from Income Aspects}

$\mathrm{CV}$ " $\mathrm{X}$ " is a small company in Tabanan Regency that produces sandals, shoes and bags. The number of workers made as respondents was 27 people and were married. Overtime work, family welfare both in terms of income and social aspects were measured using a questionnaire with 4 Likert scales. The results of the analysis show the following.

\section{- Correlation Analysis}

The results of the correlation analysis between overtime work and welfare in terms of income aspects are as follows.

TABLE I. CORRELATION BETWEEN OVERTIME AND WELFARE (INCOME)

\begin{tabular}{|c|c|c|}
\hline Variables & $\mathrm{R}$ Value & $\mathrm{p}$-value \\
\hline Overtime - Welfare (Income) & 0.817 & 0.001 \\
\hline
\end{tabular}


From Table 1, there is a significant $r$ value $(\mathrm{p}<0.05)$, this shows that there is a relationship between overtime work and welfare in terms of family income aspects.

\section{- Regression Analysis}

To see the trend and how much influence overtime work with family welfare in terms of income, linear regression analysis was carried out, with the following results.

TABLE II. OVERTIME AND INCOME WELFARE REGRESSION TABLE

\begin{tabular}{|c|c|c|c|c|c|c|c|c|}
\hline $\begin{array}{c}\text { Independent } \\
\text { var. }\end{array}$ & $\begin{array}{c}\text { Dependent } \\
\text { var. }\end{array}$ & $\mathrm{R}^{2}$ & \multicolumn{3}{|c|}{ Constant a } & \multicolumn{3}{|c|}{ Constant b } \\
\cline { 4 - 9 } & & & $\beta$ & $\mathrm{t}$ & $\mathrm{p}$ & $\beta$ & $\mathrm{t}$ & $\mathrm{p}$ \\
\hline Overtime & Income & 0.703 & 0.782 & 0.461 & 0.001 & 2.104 & 5.780 & 0.001 \\
\hline
\end{tabular}

The results show that $\mathrm{R}$ square value is 0.703 , which means that overtime work affects the income of the workers in $\mathrm{CV}$ " $\mathrm{X}$ " in Bali as much as $70.3 \%$ at $5 \%$ significance level. The regression equation would be as follows:

$$
y=0.782+2.104 x
$$

Where $\mathrm{y}$ is the variable working overtime and $\mathrm{x}$ is the variable of family welfare in terms of income aspects.

This equation shows that the coefficient on variable $\mathrm{x}$ is positive (gradient is positive). This means that the effect that occurs is a positive influence, namely the higher / often overtime work on $\mathrm{CV}$ " $\mathrm{X}$ " workers, the more prosperous their family will be (in terms of income aspects).

In line with these results, the effect of overtime on male and female workers not only affects the increase in income, but also affects the efficiency of the number of workers [7]. Compensation in work contains a professional relationship (including overtime compensation) where one of the main objectives of the employee to work is to get rewards to meet various needs (personal or family welfare), while on the company side they pay employees so that employees can carry out their work as desired and company expectations [8].

\section{Effect of Overtime Work on Family Welfare from Social Aspects}

Measurement of overtime work on family welfare in terms of social aspects was also carried out using a questionnaire given to $\mathrm{CV}$ " $\mathrm{X}$ " workers in Bali. The social aspect in question is the aspect of social relations in the family, for example the husband's togetherness with his wife and children, interaction in joint activities, providing time to pay attention, recreation, and interaction with the community around the house. The results of the questionnaire analysis are as follows.

- Correlation Analysis

The results of the correlation analysis between overtime work and welfare in terms of social aspects are as follows.

TABLE III. CORRELATION BETWEEN OVERTIME AND WELFARE (SOCIAL)

\begin{tabular}{|c|c|c|}
\hline Variables & R Value & p-value \\
\hline Overtime - Welfare (Social) & -0.514 & 0.001 \\
\hline
\end{tabular}

Obtained from Table 3 the $\mathrm{R}$ value is significant ( $\mathrm{p}$ $<0.05)$, this shows that there is a relationship between overtime work and welfare in terms of aspects of social income. However, this $r$ value has a minus sign which means that the relationship is an inverse relationship, that is, if overtime is high then family welfare from the social aspect is low or vice versa.

\section{- Regression Analysis}

To see the trend and how much influence overtime work with family welfare in terms of social aspect, linear regression analysis was carried out, with the following results.

TABLE IV. OVERTIME AND SOCIAL WELFARE REGRESSION TABLE

\begin{tabular}{|c|c|c|c|c|c|c|c|c|}
\hline $\begin{array}{c}\text { Independent } \\
\text { var. }\end{array}$ & $\begin{array}{c}\text { Dependent } \\
\text { var. }\end{array}$ & $\mathrm{R}^{2}$ & \multicolumn{3}{|c|}{ Constant a } & \multicolumn{3}{c|}{ Constant b } \\
\cline { 4 - 9 } & & & $\beta$ & $\mathrm{t}$ & $\mathrm{p}$ & $\beta$ & $\mathrm{t}$ & $\mathrm{p}$ \\
\hline Overtime & $\begin{array}{c}\text { Social } \\
\text { Aspects }\end{array}$ & 0.357 & 12.724 & 4.381 & 0.001 & -2.104 & -2.536 & 0.020 \\
\hline
\end{tabular}

The results show that $\mathrm{R}$ square value is 0.357 , which means that overtime work affects the social aspects of the workers in CV " $\mathrm{X}$ " in Bali as much as $35.7 \%$ at $5 \%$ significance level. The regression equation would be as follows:

$$
y=12.724-2.104 x
$$

Where $\mathrm{y}$ is the variable working overtime and $\mathrm{x}$ is the variable of family welfare in terms of social aspects.

This equation shows that the coefficient on variable $\mathrm{x}$ is negative (gradients are negative). This means that the effect that occurs is a negative influence (upside down), namely the higher / often overtime work on CV " $\mathrm{X}$ " workers, the lower their family welfare (in terms of social aspects).

The results of other studies also mention that there is a relationship between overtime work and productivity, melting work will cause the productivity of workers to decline [9]. Although wages given this will have a social impact on themselves and their families [10]. Comparison of work productivity overtime and normal work, and it turns out that it gives a significant difference. On the other hand, overtime work also affects the welfare and social systems of both male and female workers. More specifically for women workers, oriented to the welfare system include separate housing facilities, an enhanced security system, special facilities for the baby waiting room or breastfeeding [11]. Community social activities, family planning, investment and savings plans include those that need to be taken into account in the influence of overtime work on the social aspects.

In a review of ergonomics, optimal human working time is 8 hours a day. For heavy workers extending daily work time such as overtime work, if done too much can result in losses that usually start by increasing absenteeism due to illness due to excessive fatigue [12]. Fatigue arises from workers in the form of subjective complaints, this fatigue will reduce work productivity of workers [13], [14]. The emergence of fatigue will also reduce work motivation so that it affects work morale [15]. To overcome the effects of overtime work, there needs to be an ergonomic intervention. Ergonomic interventions can increase the work productivity of workers [16], [17]. 
Therefore, there is a need for further studies on the effects of overtime work both in terms of physical and mental health, work motivation, and other aspects.

\section{CONCLUSION AND SUGGESTIONS}

\section{A. Conclusion}

- There is working relationship overtime with family welfare. If working overtime increases then the potential for family welfare increases as well.

- Overtime work has a significant and positive influence on family welfare in terms of income aspects of workers

- Overtime work has a significant influence but a negative (inverse) influence on family welfare in terms of social aspects.

\section{B. Suggestions}

The results obtained that working overtime can have a positive influence on family welfare in terms of income, but give a negative influence on family welfare from the social aspect. So, the employers or company policyholders should give proportional overtime so that the welfare of the workers' families from the social aspect is not disrupted.

\section{ACKNOWLEDGMENT}

The authors wish to give their gratitude to the fellow college at Bali State Polytechnic for their support and to LP3M PNB for their guidance as to the development of this paper.

\section{REFERENCES}

[1] Ministry of Manpower and Transmigration and ILO Jakarta, Labour Regulations. Jakarta, 2005.

[2] S. Jaishree, "A study on labour welfare and its impact on employees' job satisfaction in garment industries, tirupur,” Int. J. Manag. Soc. Sci., vol. 3, no. 4, pp. 86-95, 2015

[3] BKKBN, Guidelines for the development of prosperous families in the context of increasing poverty reduction. Jakarta: Office of the Minister of Population (Indonesia), 2006.

[4] McConnel, C. R., S. L. Brue, and D. A. Macpherson, Contemporary Labor Economics. New York: McGraw-Hill, 2003.
[5] Congressional Business Office, The effects of a minimum-wage increase on employment and family income, no. February. 2014.

[6] S. KT, "A Study on employees welfare facilities adopted at bosch limited , bangalore," vol. 2, no. 12, pp. 7-11, 2013.

[7] R. Oaxaca, "The effect of overtime regulations on employment," IZA World Labor, no. October, pp. 1-10, 2014.

[8] R. Santhanakrishnan and M. Rajarajan, "Labour welfare measures and programmes towards transport corporation limited in tamil nadu," Int. J. World Res., vol. 1, no. 20, pp. 51-58, 2014.

[9] N. C. Man and T. W. Ling, "Relationships between working hours and productivity: the case of food services and information communication industries in hong kong," Adv. Econ. Bus., vol. 2, no. 7, pp. 281-292, 2014.

[10] C. Caruso, E. D. Hitchcock R. Russo. J. Schimt, J., and Anonymous, overtime and extended work shifts: recent findings on illness, injuries and health behaviours., vol. 143. Columbia: U.S. Department of Health and Human Services, 2004.

[11] J. Das, "Voluntary labour welfare schemes: measures adopted by garment export units in bangalore, india," Int. J. Busines Manag., vol. 4, no. 5, pp. 412-418, 2016.

[12] HSE, Ergonomics and human factors at work, A brief guide. 2013.

[13] I. K. Dunia, M. Yusuf, M. A. Santiasa, and I. D. A. S. Suasmini, "The use of used truck pneumatic tires as an aid in decreasing workload of the rock transporting workers and increasing their productivity in Sampalan Kaja Village in dawan subdistrict in Klungkung regency," in Proceedings - Ergo Future 2006, International Symposium on Past, Present and Future Ergonomics, Occupational Safety and Health, 2006.

[14] M. Yusuf and A. A. Mulawarman, "Improvement of working room ventilation can decrease work load and increase work productivity of roasted fishes workers in cafe ' $\mathrm{X}$ ' Jimbaran Badung regency," in Proceedings - Ergo Future 2006, International Symposium on Past, Present and Future Ergonomics, Occupational Safety and Health, 2006.

[15] M. A. Santiana, M. Yusuf, and W. D. Lokantara, "Mother chair reparation to decrease subjective disorders in exclusive breast-feeding period,”J. Phys. Conf. Ser., vol. 953, no. 1, 2018.

[16] M. Yusuf, M. Santiana, and W. D. Lokantara, "Improvement of work posture to decrease musculoskeletal disorder and increase work productivity jewelry worker in bali," in Proceeding International Joint Conferenceon Science and Technology (IJCST) pp. 242-247, 2017.

[17] I. K. G. J. Suarbawa, M. Arsawan, M. Yusuf, and I. M. Anom Santiana, "Improvement of environment and work posture through ergonomic approach to increase productivity of balinese kepeng coin workers in Kamasan village Klungkung Bali,” in Journal of Physics: Conference Series, vol. 953, no. 1, 2018. 